\title{
Measuring the hoteliers' interactive engagement through social media
}

\author{
By Mark Anthony Camilleri' ${ }^{1}$ (Ph.D. Edinburgh) University of Malta, Malta.
}

How to Cite: Camilleri, M.A. (2019). Measuring the hoteliers' interactive engagement through social media. In Liargovas, P \& Kakouris, A. (Eds.) $14^{\text {th }}$ European Conference on Innovation and Entrepreneurship (ECIE2019), University of Peloponnese, Kalamata, Greece.

\begin{abstract}
The hospitality businesses are increasingly using the interactive technologies to promote their services and to engage with online prospects. Therefore, this study explores the hospitality executives' stance toward the acceptance and use of social media for marketing purposes. The methodology relied on valid and reliable measures, including; the Technology Acceptance Model's 'perceived usefulness' and 'ease of use' of technology, as well as the Theory of Planned Behavior's 'social influences' and 'behavioral intention'. Moreover, it adapted other constructs that were previously used to measure 'interactive engagement' and 'pace of technological innovation'. The research model investigated whether these constructs had a significant effect on the participants' intention to use social media for interactive engagement. The results have supported the scales' content validity and the structural equations modeling approach has reported a satisfactory fit for this study's research model. The findings indicated that there were highly significant, direct and indirect effects from the exogenous variables, particularly from the perceived usefulness and social influences that were predicting the hospitality owner-managers' behavioral intentions to use social media. The individuals' utilitarian motives to use the social media were clearly evidenced as they perceived the usefulness of the social media. They also indicated that they were influenced by their colleagues or competitors. Notwithstanding, there were significant influences from the demographic variables, including age, gender and experiences that moderated these relationships. This research model has integrated previously tried and tested measures relating to the acceptance and use of technology. In sum, this study reported that the younger, female respondents were more likely to use the social media to engage with online prospects, when compared with their older counterparts. In conclusion, this contribution identifies its limitations and suggests possible research avenues to academia.
\end{abstract}

Keywords: Theory of Planned Behavior, Technology Acceptance Model, Social media; Pace of Technological Innovation; Interactive Engagement; Structural Equation Modelling.

\footnotetext{
${ }^{1}$ Department of Corporate Communication, Faculty of Media and Knowledge Sciences, University of Malta, MAKS Building (Room 506), Msida, MSD2080, MALTA. Email: mark.a.camilleri@um.edu.mt
} 


\section{Introduction}

The hospitality businesses are increasingly promoting their products and services through different channels. The hotel and restaurant owner-managers are encouraged to use content marketing on social media (including social networks, blogs, wikis, electronic fora, webinars, podcasts, videos, et cetera) to reach wider audiences. They can publish relevant content online, at the right place and at the right time. This content can be targeted at particular segments, niches or individual prospects. Notwithstanding, high quality content is often co-created by the online users' (Harrigan \& Miles, 2014), as the Internet's lack of gatekeeping has led to an increased engagement between participants. The interactive media has enabled the emergence of a new participatory public sphere where everybody could dialogically interact and collaborate in the co-creation of content (Lamberton \& Stephen, 2016; Kaplan \& Haenlein, 2010).

The communications through social media are dynamic and in real time. Online users hold the technological potential to increase direct interactions with organizations and other audiences (Camilleri, 2017). Such interactive communications are often referred to as "viral" because ideas and opinions can spread through the web via word-of-mouth. Moreover, there are several online channels that are including highly scalable, social media networks and product recommender systems that feature independent reviews and rankings. These channels are often perceived as highly trustworthy sources by prospective customers (Filieri, 2016). The emergence of such user-generated content in fora, newsgroups, social media and crowdsourcing have led to positive or negative word of mouth publicity on brands, products and services. Such communicative features have become widely pervasive online. (Tiago \& Veríssimo 2014; Kaplan \& Haenlein, 2010). For this reason, the hoteliers need to acquaint themselves with the use of social media in order to increase the impact of their communications. There is an opportunity for them to use interactive technologies to increase the frequency and 
reach of their messages (Kaplan \& Haenlein, 2010). The hotels' marketing executives could embrace the social media to amplify the impact of their message. However, they need to create the right message to reach out to their chosen prospects. However, the businesses' online engagement is neither automatic nor easy (Tiago \& Veríssimo, 2014). The dialogic features that are enabled by web pages, blogs, and other social media may prove difficult to apply. To date, little empirical research has measured the hospitality owner-managers' stance toward social media. Previous studies reported that there are still many businesses that are not benefiting enough of the social media, as they did not untap its full potential (Taiminen \& Karjaluoto, 2015). Perhaps, they may not consider interactive marketing as effective communications channels to promote products and services. Many businesses may not use the Internet technologies to promote their products. (Camilleri, 2018), or they may rely on traditional advertising and promotions. Alternatively, the hoteliers may lack the digital competences and skills to engage with their online prospects; or may not have time and resources to engage in social media (Brouthers, Nakos \& Dimitratos, 2015).

This contribution addresses a knowledge gap in academic literature as it examines the hospitality owner-managers' technology acceptance and their behavioral intentions to engage in interactive technologies. Therefore, this research has adapted valid and reliable measures that explored the respondents' pace of technological innovation, social influences, as well as their perceptions on the usefulness and the ease of use of digital. Moreover, this study examined if the participants' behavioral intention and their engagement with interactive technologies. This research investigated whether the chosen constructs were affected by the demographic variables, including age, gender and experiences as it sheds light on the causal path that explains the rationale behind the hotel and restaurant owner-managers' utilization of social media for marketing and promotions. 


\section{The conceptual development and the formulation of hypotheses}

\subsection{The behavioral intention to use social media for interactive engagement with online}

users

A thorough literature review suggests that there are a number of theoretical frameworks, including; the Theory of Reasoned Action (Fishbein \& Ajzen, 1975), the Technology Acceptance Model (Davis 1989; Davis, Bagozzi \& Warshaw, 1989); the Theory of Planned Behavior (Ajzen 1991); the Unified Theory of Acceptance and Use of Technology (Venkatesh, Morris, Davis \& Davis, 2003) among others. Their measures have often been used in academia, as researchers have frequently explored the individuals' engagement with technology, in different contexts. For instance, the theory of reasoned action (TRA) sought to explain the relationship between attitudes and the behaviors of individuals. Fishbein and Ajzen's (1975) suggested that the individuals' decision to engage in a particular behavior is based on the outcomes that they expect. Therefore, this model implies that the individuals' intention and motivation to perform certain actions will precede their actual behaviors. The persons' intentions are determined by their behavioral attitudes and subjective norms (Fishbein \& Ajzen, 1975). Hence, TRA included four general concepts: behavioral attitudes, normative pressures, behavioral intention, and actual behavior. The normative pressure or the "subjective norm has a direct effect on the individuals' behavioral intention (Fishbein \& Ajzen, 1975, p. 302). The individuals may be influenced by others to use technology. Ajzen (1991) has extended Fishbein and Ajzen's (1975) TRA by introducing the behavioral control construct in the Theory of Planned Behavior (TPB). He argued that the "perceived control" is the "people's perception of the ease or difficulty of performing the behavior of interest" (p. 183). According to the TPB, the individuals' perceived behavioral control is an antecedent of the individuals' intention to use technology as it reflects their internal and external constraints on behavior. The behavioral control construct was used in previous studies to measure the extent to which individuals 
believe that they are capable of using technology. The individuals may have different beliefs on the degree of effort and on the persistence of their effort that would be required to use technologies.

Davis' (1989) Technology Acceptance Model (TAM) has also been widely used in academic literature to explore the individuals' perceived use, ease of use and attitudes toward different technologies (Wu \& Chen, 2017; Rauniar, Rawski, Yang \& Johnson, 2014). However, despite its popularity in academic literature, there were many researchers that pointed out that were other factors that could influence the usage of technology. Venkatesh and Davis (2000) recommended that TAM should be supplemented and extended by using the subjective norm from the TPB. Eventually, Venkatesh et al. (2003) have integrated elements from different theoretical models and empirically validated them in their Unified Theory of Acceptance and Use of Technology (UTAUT) model. The authors held that the individuals' behavioral intention had a significant positive influence on their usage of the technology. They went on to suggest that this effect decreases as experience increases. A greater usage experience implies more opportunities to strengthen the link between cues and behavior (Venkatesh et al., 2012; Park, Nam \& Cha, 2012). This leads to the first hypothesis:

H1: The individuals' intention to use the social media has a positive and significant effect on their interactive engagement with online users. This influence is moderated by experience.

\subsection{The pace of technological innovation}

The web is advancing at an unprecedented pace of technology. Its users have transformed the Internet as they engage with others in real time. Previous literature reported that many hoteliers are also utilizing these technological innovations, including; social media platforms as they engage with individual users and online communities (Litvin, Goldsmith, \& Pan, 2018; 
Camilleri, 2018; Kim, Lim \& Brymer, 2015). Notwithstanding, there have been significant developments in recommender systems that rely on big data and analytics, among other technologies (Xie, So \& Wang, 2017; Murphy, Chen \& Cossutta, 2016). The emergence of user-generated content in fora, newsgroups, social media and crowd-sourcing have offered endless opportunities to hotel practitioners to "listen" to their customers (Lee, Jeong \& Lee, 2017; Herrero, San Martín, \& Hernández, 2015). Therefore, many hospitality executives are already using the social media to engage in online conversations with their stakeholders (Camilleri, 2017). They are encouraged to use these smart technologies to facilitate the creation of more meaningful and personalized services and experiences (Neuhofer, Buhalis \& Ladkin, 2015; Greenhow \& Robelia, 2009). In this light, this research investigates the participants' attitudes toward the adoption and diffusion of social media. This study presumes that it is in the hospitality owner-managers' interest to keep themselves up-to-date with the pace of technological innovation. This leads to the second hypothesis:

H2: The individuals' pace of technological innovation has a positive and significant effect on their intention to utilize this technology for interactive engagement with online users. This influence is moderated by age, gender and experience.

\subsection{Perceived usefulness of social media}

Davis (1989) maintained that the perceived usefulness construct (PU) has to do with the degree to which a person believes that the technology will help him or her to perform a certain task in an efficient and productive manner. Hence, PU is concerned with the expected overall impact of technology on the individual's job performance (in terms of process and outcome). Turner, Kitchenham, Brereton, Charters and Budgen (2010) elaborated that technology is often used to improve the working practices by increasing productivity, quality or timeliness of products and 
services. However, Venkatesh et al. (2003) suggested that the demographic variables can have an effect on the adoption of technology adoption. This leads to the third hypothesis:

H3: The individuals' perceived usefulness of social media has a positive and significant effect on their intention utilize this technology for interactive engagement with online users. Age, gender and experience will moderate this effect.

\subsection{Perceived ease of use of social media}

Davis (1989) explored the extent to which a person thinks that the technology is user-friendly and free of effort. Venkatesh et al. (2003) suggested that effort-oriented constructs were evidenced during the early stages of technology adoption, when the users may encounter process issues when they are still learning on how to use the technology. Individuals may feel uneasy, apprehensive, or fearful of using computers (Meuter, Bitner, Ostrom \& Brown, 2005). Therefore, the ease of use of the technologies can have an impact on the individuals' intention to use them. Venkatesh et al. (2012) posited that age, gender and experience may influence the relationship between effort expectancy (or perceived ease of use) and behavioral intention to use the technology. This leads to the fourth hypothesis:

H4: The individuals' perceived ease of use of social media has a positive and significant effect on their intention to utilize this technology for interactive engagement with online users. Age, gender and experience will moderate this effect.

\subsection{Social influences}

Individuals may be influenced by others, including their family and friends, to use the technological innovations (Venkatesh \& Davis, 2000). The social influence construct (SI) is "the degree to which an individual perceives that important others believe he or she should use 
the new system" (Venkatesh et al., 2003, p. 451). The normative pressures appear to be important in the early stages of individual experience with the technology. The social influences can have an impact on the individuals' behavior through; compliance, internalization, and identification (Venkatesh \& Davis, 2000). While the compliance mechanism causes individuals to alter their intention in response to the societal pressures, the latter two variables relate to the individuals' changing beliefs as they respond to comply with social influences. Venkatesh et al. (2003) contended that over time this construct becomes nonsignificant with sustained usage. Such normative pressures may attenuate over time through increased use of technology. Moreover, the demographic variables, including gender may have an influence on the relationship between the social influence and the users' intention to use technology (Venkatesh \& Davis, 2000). The males and female genders may respond in a different manner to the societal pressures as they may be driven by psycho-social phenomena to behave the way they do. Notwithstanding, the individuals' age may also affect whether individuals rely on social influences (Morris \& Venkatesh 2000). This leads to the fifth hypothesis.

H5: The individuals' social influences can have a positive and significant effect on their intention to utilize this technology for interactive engagement with online users. Age and gender will moderate this effect.

\subsection{The research model}

This study has adapted the constructs from the Technology Acceptance Model and from the Theory of Planned Behavior. In sum, it hypothesizes that the individuals' pace of technological innovation, social influences, as well as their perceived usefulness and ease of use of social media are the antecedents of their behavioral intention to utilize the social media for interactive 
engagement with online users. Moreover, it presumes that the demographic variables, including age, gender and experience could mediate these relationships, as illustrated in Figure 1.

Figure 1. A Research Model on the Users' Interactive Engagement with Technology

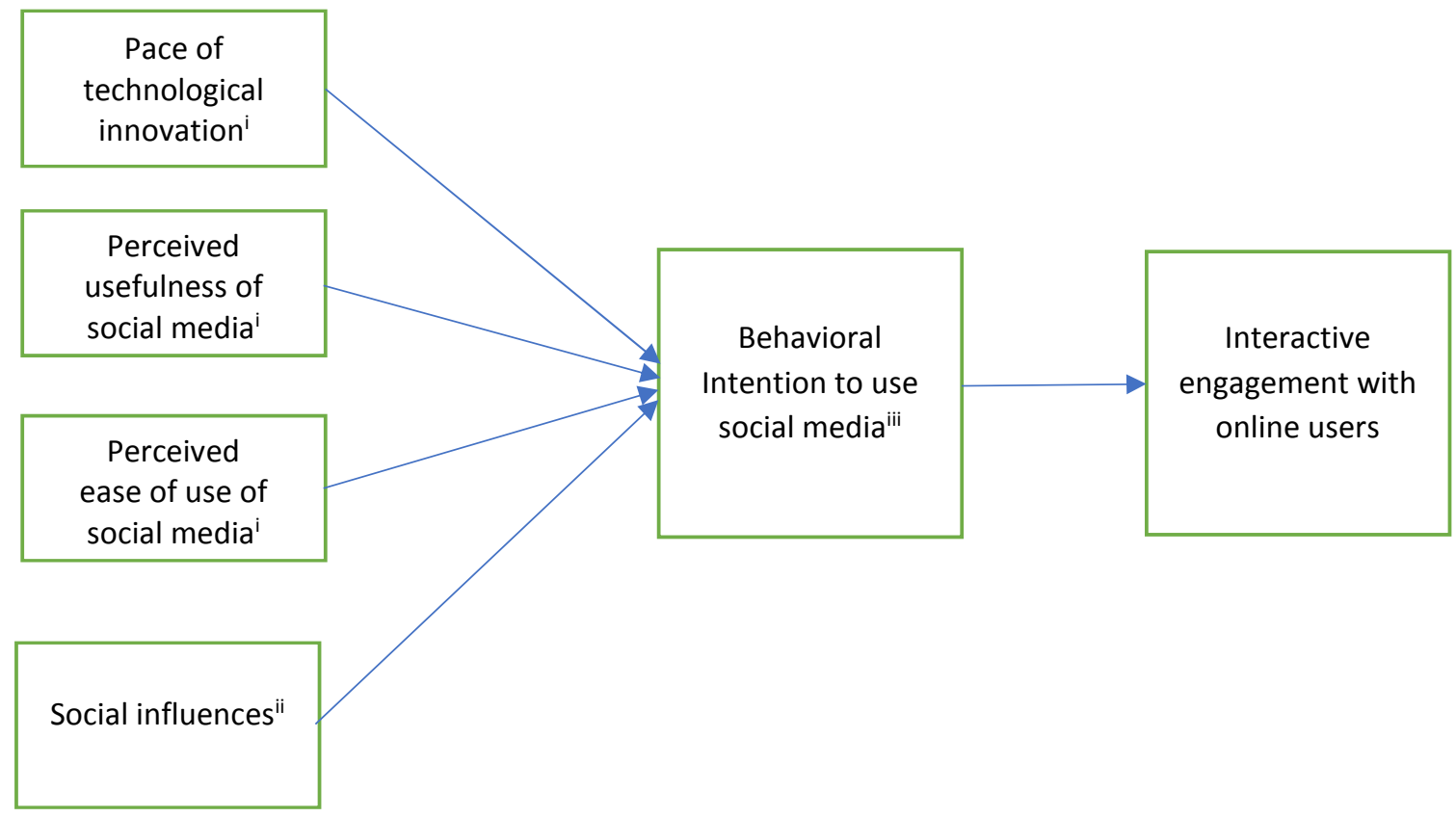

i. Moderated by age, gender and experience.

ii. Moderating by age and gender.

iii. Moderated by experience.

\section{The research method}

The survey questionnaires were distributed by email among hospitality owner-managers and executives who were members in hotel and restaurant associations in a southern European state. The emails generated 1,783 hits on the questionnaire's website. Of these, 248 respondents have submitted useable data sets. The respondents could not participate more than once in the survey as they could not use the same IP address. 


\subsection{The measures}

The research participants were expected to indicate the extent of their agreement with the survey items, in a seven-point Likert scale. The responses ranged from 1= "strongly disagree" to $7=$ "strongly agree", where 4 signaled an indecision. This study adapted valid and reliable measures that included; Grewal, Mehta and Kardes, (2004) 'pace of technological innovation'; Davis' (1989) and Davis et al.'s (1989) 'perceived ease of use' and 'perceived use'; Ajzen's (1991) 'social influences' and behavioral intention, as well as McMillan and Hwang's (2002) 'engaging' construct.

The participants were expected to disclose their age by choosing one of seven age groups. They indicated their gender that was coded by using the 1 or 0 dummy variable, where 0 represented women. The respondents revealed their experience, that was measured in months. The questionnaire was pilot tested among a small group of post graduate students, who were not included in the survey results to ensure that the scales were reliable and valid before administering of the survey to the research participants.

\subsection{The demographic profile of the respondents}

The surveyed respondents gave their socio-demographic details about their 'gender', 'age' and 'experience' in the latter part of the survey questionnaire. Table 1 presents the profile of respondents that participated in this study: 
Table 1. The demographic profile of respondents

\begin{tabular}{|l|l|}
\hline \multicolumn{2}{|c|}{ Gender } \\
\hline Female & 185 \\
\hline Male & 63 \\
\hline & \\
\hline & \\
\hline & \\
\hline & \\
\hline $\mathrm{N}=248$ \\
\hline
\end{tabular}

\begin{tabular}{|l|l|}
\hline \multicolumn{2}{|c|}{ Age } \\
\hline $16-25$ years & 7 \\
\hline 26-35 years & 53 \\
\hline $36-45$ years & 99 \\
\hline $46-55$ years & 48 \\
\hline $56-65$ years & 32 \\
\hline $66-75$ years & 6 \\
\hline More than 76 years & 1 \\
\hline mean & 44 years \\
\hline \multicolumn{2}{|c|}{ N=246 } \\
\hline
\end{tabular}

\begin{tabular}{|l|l|}
\hline \multicolumn{2}{|c|}{ Experience } \\
\hline $0-12$ months & 5 \\
\hline $13-24$ months & 2 \\
\hline 25-36 months & 10 \\
\hline 37-48 months & 8 \\
\hline $49-60$ months & 26 \\
\hline 61-72 months & 49 \\
\hline More than 73 months & 148 \\
\hline & \\
\hline \multicolumn{2}{|c|}{$\mathrm{N}=248$} \\
\hline
\end{tabular}

\section{Data analysis}

\subsection{Descriptive statistics}

There were one hundred and eighty-five females and sixty-three males who have participated in this study. The respondents' 'age' varied, and this was evident in the standard deviation $(\sigma)$ of 0.71 . Respondents were also classified into six age groups $(16-25 ; 26-35 ; 36-45 ; 46-55,56-$ 65, 66-75 and over 76 years of age). The majority of the respondents were aged between 36 and 45 years of age $(n=99)$, followed by those aged between 26 and 35 years $(n=53)$. The majority of respondents $(n=148)$ indicated that they had acquired more than six years of experience on social media. Whereas, there were twenty-five $(n=25)$ respondents who started using social media in the past four years. Generally, the respondents agreed with the survey items in the model, as the mean scores were well above the mid-point of 4.0. Moreover, the standard deviations indicated that there was a narrow spread of participants' responses, ranging 
from 0.3 to 1.4 , indicating a narrow spread around the mean. The skewness and the kurtosis indices met Kline's (2005) recommendations for the purposes of SEM.

\subsection{Evaluation of the measurement model}

The measurement model involved a confirmatory factor analysis (CFA). This was conducted through Structural Equation Modelling in order to assess the uni-dimensionality, validity and reliability of the constructs. CFA removed the items that did not fit the measurement model due to low factor loading. The researcher conducted a pooled CFA to assess the measures of the latent constructs. The uni-dimensionality was achieved as all factor loadings were positive and higher than 0.6. There was evidence of convergent validity as all items in the measurement model were statistically significant. The values of the average variance extracted (AVE) were higher than 0.5. Moreover, there was construct validity as the Fitness Indexes of the latent constructs achieved the required level.

\subsection{The confirmatory factor analysis}

The CFA results have indicated the fitness indices and factor loading for every item together with their respective R2. The correlations between constructs were computed simultaneously. There was discriminant validity as the model exhibited low modification indices $(\mathrm{MI}<14)$ and the correlation between the exogenous constructs did not exceed 0.85 . The results reported a satisfactory model fit: $\chi^{2}=441.240 ; \chi^{2} / \mathrm{df}=2.97$;LI= 0.962; CFI= 0.951; RMSEA=0.046; $\mathrm{SRMR}=0.027$

\subsection{The validity and reliability of the research model}

The Convergent Validity for the measurement model was achieved as all AVE values exceeded 0.50. The Construct Validity for the measurement model was achieved as all Fitness Indexes met the required level. The Discriminant Validity was also achieved when all redundant items 
were deleted. Moreover, the Composite Reliability was achieved as all CR values exceeded 0.60. Table 2 reports the findings from the CFA for every construct, including the factor loadings, CR and AVE.

The constructs in the model were discriminant of each other as reported in Appendix A. The discriminant validity was achieved as the bold diagonal value (i.e. the square roots of AVE) were higher than the correlations among the constructs. This study followed Venkatesh et al.'s (2012) procedure to illustrate the structural model results. Two models tested the direct and moderated effects of the adapted UTAUT model. 
Table 2. The confirmatory factor analysis

\begin{tabular}{|c|c|c|c|c|}
\hline \multicolumn{2}{|c|}{ Construct and Items } & & FL & $\mathbf{C R}$ \\
\hline \multirow{6}{*}{$\begin{array}{l}\text { Pace of } \\
\text { Technological } \\
\text { Innovation } \\
(\mathrm{AVE}=\mathbf{0 . 7 9 )}\end{array}$} & PTI1 & Social media is changing at a fast pace & \multirow{2}{*}{$\begin{array}{l}0.79 \\
0.74 \\
\end{array}$} & \multirow{6}{*}{0.81} \\
\hline & \multirow{2}{*}{$\begin{array}{l}\text { PTI2 } \\
\text { PTI3 }\end{array}$} & $\begin{array}{l}\text { Social media is changing at a fast pace } \\
\text { Compared to other technologies, } \\
\text { social media are changing fast }\end{array}$ & & \\
\hline & & $\begin{array}{l}\text { I have consistently seen new } \\
\text { technology in social media for some } \\
\text { time }\end{array}$ & 0.75 & \\
\hline & PTI4 & $\begin{array}{l}\begin{array}{l}\text { Innovations in social media are } \\
\text { frequent }\end{array} \\
\end{array}$ & 0.74 & \\
\hline & PTI5 & $\begin{array}{l}\text { The pace of technological innovation } \\
\text { in hospitality is high }\end{array}$ & 0.69 & \\
\hline & PTI6 & $\begin{array}{l}\text { Technological innovation and } \\
\text { hospitality don't go hand in hand }(\mathrm{R})\end{array}$ & 0.65 & \\
\hline \multirow{3}{*}{$\begin{array}{l}\text { Perceived } \\
\text { Usefulness } \\
\text { (AVE=0.82) }\end{array}$} & PU1 & $\begin{array}{l}\text { I find social media useful in my daily } \\
\text { life }\end{array}$ & 0.8 & \multirow{3}{*}{0.82} \\
\hline & PU2 & $\begin{array}{l}\text { Social media increase my chances of } \\
\text { achieving things that are important to } \\
\text { me }\end{array}$ & 0.78 & \\
\hline & PU3 & $\begin{array}{l}\text { Social media help me accomplish } \\
\text { things more quickly }\end{array}$ & 0.65 & \\
\hline \multirow{4}{*}{$\begin{array}{l}\text { Perceived } \\
\text { Ease of Use } \\
(\mathrm{AVE}=\mathbf{0 . 7 4})\end{array}$} & PEU1 & $\begin{array}{l}\text { Learning how to use social media is } \\
\text { easy for me }\end{array}$ & 0.91 & \multirow{4}{*}{0.89} \\
\hline & PEU2 & $\begin{array}{l}\text { My interaction with social media is } \\
\text { clear and understandable }\end{array}$ & 0.88 & \\
\hline & PEU3 & I find social media easy to use & 0.86 & \\
\hline & PEU4 & $\begin{array}{l}\text { It is easy for me to become skillful at } \\
\text { using social media }\end{array}$ & 0.82 & \\
\hline \multirow{3}{*}{$\begin{array}{l}\text { Social } \\
\text { Influences } \\
(\mathrm{AVE}=\mathbf{0 . 7 2})\end{array}$} & SI1 & $\begin{array}{l}\text { People who are important to me think } \\
\text { that I should use social media }\end{array}$ & 0.79 & \multirow{3}{*}{0.85} \\
\hline & SI2 & $\begin{array}{l}\text { People who influence my behavior } \\
\text { think that I should use social media }\end{array}$ & 0.92 & \\
\hline & SI3 & $\begin{array}{l}\text { People who are important to me } \\
\text { would prefer that I use social media }\end{array}$ & 0.87 & \\
\hline \multirow{3}{*}{$\begin{array}{l}\text { Behavioral } \\
\text { Intention } \\
(\mathrm{AVE}=\mathbf{0 . 9 1})\end{array}$} & BI1 & $\begin{array}{l}\text { It is very likely that I shall continue } \\
\text { using social media in the future }\end{array}$ & 0.81 & \multirow{3}{*}{0.91} \\
\hline & $\mathrm{BI} 2$ & $\begin{array}{l}\text { Probably, I will use social media in } \\
\text { my daily life }\end{array}$ & 0.82 & \\
\hline & $\mathrm{BI} 3$ & $\begin{array}{l}\text { I will use social media as frequently as } \\
\text { possible }\end{array}$ & 0.79 & \\
\hline \multirow{7}{*}{$\begin{array}{l}\text { Interactive } \\
\text { Engagement } \\
(\mathrm{AVE}=\mathbf{0 . 8 8})\end{array}$} & ENG1 & Social media offer a variety of content & 0.88 & \multirow{7}{*}{0.89} \\
\hline & ENG2 & $\begin{array}{l}\text { It is easy to find my way through the } \\
\text { social media }\end{array}$ & 0.85 & \\
\hline & ENG3 & Social media keep my attention & 0.74 & \\
\hline & ENG5 & $\begin{array}{l}\begin{array}{l}\text { Social media do not keep my } \\
\text { attention* }\end{array} \\
\end{array}$ & 0.68 & \\
\hline & ENG6 & Social media are passive* & 0.65 & \\
\hline & ENG7 & $\begin{array}{l}\text { Social media provide immediate } \\
\text { answers to questions }\end{array}$ & 0.80 & \\
\hline & ENG8 & Social media lack content* & 0.69 & \\
\hline
\end{tabular}




\section{An Interpretation of the Findings}

This study has supported and validated key constructs, including the Technology Acceptance Model's perceived usefulness and the perceived ease of use (Davis, 1989), as well as the Theory of Planned Behavior's 'social influences' and 'behavioral intention' (Ajzen, 1991). Moreover, it adapted measures from McMillan and Hwang's (2002) 'engaging' construct from their study on perceived interactivity and has utilized Grewal et al.'s (2004) 'pace of technological innovation'.

The results suggest that most of the hypothesized relationships were positive and significant. The findings from the structural equations modeling approach reported a satisfactory fit for this study's research model. Overall, the direct effects represented 39 percent of the variance that predicted intention, whilst the interaction terms explained 65 percent of the variance. In a similar vein, there was 41 percent of the variance that can be attributed to the direct effects, and 54 percent of the variance comprised the mediating effects. The results suggest that there were highly significant, direct effects that predicted the hospitality owner-managers' behavioral intentions to engage with online users via social media. The individuals' utilitarian motives to use the social media were clearly evidenced in the perceived usefulness measuring items (Davis et al., 1989). Evidently, the respondents perceived the usefulness of the social media as there were very significant direct effects $(\mathrm{p}<0.001)$ as well as significant indirect effects $(\mathrm{p}<0.05)$ on the users' intention to use the social media. In addition, the online users indicated that they were influenced by their colleagues or competitors as there were significant direct and indirect effects on their behavioral intention to utilize social media. Moreover, there were significant moderating influences from the demographic variables, including age, gender and experiences on other exogenous variables that have inevitably affected the respondents' perceptions on the technological innovations. 
The users' behavioral intentions predicted their usage of technology $(\mathrm{H} 1)$. The results indicated that the respondents' intention had a highly significant, direct influence $(0.31)$ on their interactive engagement with other online users through social media, where $\mathrm{p}<0.001$. Moreover, there was a significant $(\mathrm{p}<0.05)$, indirect influence $(0.13)$ between intention and engagement. The findings reported that the pace of technological innovation was also a very significant antecedent that predicted the users' intention to use social media $(0.14)$, where $\mathrm{p}<0.01(\mathrm{H} 2)$. Yet, this study reported that there was no relationship between the pace of technological innovation and intention when the interaction terms were inserted in the structured equation. In a similar vein, there were no interaction terms that were influencing the relationship between the individuals' perceived ease of use and their intention to use the social media. These findings suggest that age, gender and experience did not mediate the relationship between the pace of technological innovation and /or between perceived ease of use of social media and intention. Evidently, the participants did not consider the social media technologies to be difficult to use. The perceived usefulness had a direct effect $(0.31)$ on intention, and this influence was highly significant at $\mathrm{p}<0.001(\mathrm{H} 3)$. However, in this case, there was an indirect effect $(0.13)$ from the mediating variables in the perceived usefulness - behavioral intention relationship. There were significant, direct relationships between perceived ease of use $(0.27)$ and social influence $(0.18)$ with the individuals' intention to use social media, where $\mathrm{p}<0.05$ (H4 and H5).

In sum, the perceived usefulness appears to be a determinant for the users' behavioral intention to engage with social media, in most situations: The strength of this relationship varies with gender and age such that it is more significant among the younger individuals. Interestingly, the effect of perceived ease of use on engagement is moderated by age as well as gender, such that it is more significant among females. The results indicate that those effects decrease with experience. 


\section{Limitations and future research}

To date, there have been a few studies that have explored the hoteliers' perceptions on the use of social media for interactive engagement. In this case, the number of participants was more than sufficient to draw significant conclusions and implications from the results. However, one of the limitations of this study concerns the skewness of the sampling frame. The respondents in this study were mostly middle-aged females. As a result, the findings of this study may not apply to the other demographic groups. Future contributions can replicate this study in different contexts, across various industry sectors. Alternatively, other research can build on this study by including more utilitarian and / or hedonic constructs in order to explore the effect of other exogenous constructs on the individuals' behavioral intention to use social media.

\section{References}

Ajzen, I. (1991) "The Theory of Planned Behavior", Organizational Behavior and Human Decision Processes, Vol. 50, No. 2, pp. 179-211.

Brouthers, K. D., Nakos, G. and Dimitratos, P. (2015) "SME Entrepreneurial Orientation, International Performance, and the Moderating Role of Strategic Alliances", Entrepreneurship Theory and Practice, Vol. 39, No. 5, pp. 1161-1187.

Camilleri, M.A. (2017) "The Promotion of Responsible Tourism Management Through Digital Media", Tourism Planning \& Development, Vol. 15, No. 6, pp. 653-671.

Camilleri, M.A. (2018) “The SMEs' Technology Acceptance of Digital Media for Stakeholder Engagement", Journal of Small Business and Enterprise Development, https://www.emeraldinsight.com/doi/abs/10.1108/JSBED-02-2018-0042

Davis, F.D. (1989) "Perceived Usefulness, Perceived Ease of Use, and User Acceptance of Information Technology", MIS Quarterly, pp. 319-340.

Davis, F.D., Bagozzi, R.P. and Warshaw, P.R. (1989) "User Acceptance of Computer Technology: A Comparison of Two Theoretical Models", Management Science, Vol. 35, No. 8, pp. 982-1003.

Filieri, R. (2016) What makes an Online Consumer Review Trustworthy? Annals of Tourism Research, Vol. 58, pp. 46-64.

Fishbein, M. and Ajzen, I. (1975) "Belief, Attitude, Intention, and Behavior: An Introduction to Theory and Research", Addison-Wesley, Reading, MA, USA. 
Grewal, R., Mehta, R. and Kardes, F.R. (2004) "The Timing of Repeat Purchases of Consumer Durable Goods: The Role of Functional Bases of Consumer Attitudes", Journal of Marketing Research, Vol. 41, No. 1, pp. 101-115.

Harrigan, P. and Miles, M. (2014) "From e-CRM to s-CRM. Critical Factors Underpinning the Social CRM Activities of SMEs", Small Enterprise Research, Vol. 21, No. 1, pp. 99-116.

Herrero, Á., San Martín, H. and Hernández, J.M. (2015) "How Online Search Behavior is Influenced by User-Generated Content on Review Websites and Hotel Interactive Websites", International Journal of Contemporary Hospitality Management, Vol. 27, No. 7, pp. 1573-1597.

Kaplan, A.M. and Haenlein, M. (2010) "Users of the World, Unite! The Challenges and Opportunities of Social Media”, Business Horizons, Vol. 53, No. 1, pp. 59-68.

Kim, W.G., Lim, H. and Brymer, R.A. (2015) "The Effectiveness of Managing Social Media on Hotel Performance", International Journal of Hospitality Management, Vol. 44, pp. 165171.

Kline, R.B. (2005) "Principles and Practice of Structural Equation Modeling" (2nd ed.), Guilford Press, New York, USA.

Lamberton, C. and Stephen, A.T. (2016) "A Thematic Exploration of Digital, Social Media, and Mobile Marketing: Research Evolution from 2000 to 2015 and an Agenda for Future Inquiry", Journal of Marketing, Vol. 80, No. 6, pp. 146-172.

Lee, M., Jeong, M. and Lee, J. (2017) 'Roles of Negative Emotions in Customers' Perceived Helpfulness of Hotel Reviews on a User-Generated Review Website: a Text Mining Approach", International Journal of Contemporary Hospitality Management, Vol. 29, No. 2 , pp. 762-783.

Litvin, S.W., Goldsmith, R.E. and Pan, B. (2018) "A Retrospective View of Electronic Wordof-Mouth in Hospitality and Tourism Management", International Journal of Contemporary Hospitality Management, Vol. 30, No. 1, pp. 313-325.

McMillan, S.J. and Hwang, J.S. (2002) "Measures of Perceived Interactivity: An exploration of the Role of Direction of Communication, User Control, and Time in Shaping Perceptions of Interactivity", Journal of Advertising, Vol. 31, No. 3, pp. 29-42.

Morris, M.G. and Venkatesh, V. (2000) "Age Differences in Technology Adoption Decisions: Implications for a Changing Workforce”, Personnel Psychology, Vol. 53, No. 2, pp. 375-403.

Murphy, H.C., Chen, M.M. and Cossutta, M. (2016) "An Investigation of Multiple Devices and Information Sources used in the Hotel Booking Process", Tourism Management, Vol. 52, pp. 44-51.

Neuhofer, B., Buhalis, D. and Ladkin, A. (2015) "Smart Technologies for Personalized Experiences: A Case Study in the Hospitality Domain", Electronic Markets, Vol. 25, No. 3, pp. 243-254. 
Rauniar, R., Rawski, G., Yang, J. and Johnson, B. (2014) "Technology Acceptance Model (TAM) and Social Media Usage: An Empirical Study on Facebook", Journal of Enterprise Information Management, Vol. 27, No. 1, pp. 6-30.

Taiminen, H.M. and Karjaluoto, H. (2015) "The Usage of Digital Marketing Channels in SMEs", Journal of Small Business and Enterprise Development, Vol. 22, No. 4, pp. 633-651.

Tiago, M.T.P.M.B. and Veríssimo, J.M.C. (2014) "Digital Marketing and Social Media: Why Bother?", Business Horizons, Vol. 57, No. 6, pp. 703-708.

Turner, M., Kitchenham, B., Brereton, P., Charters, S. and Budgen, D. (2010) "Does the Technology Acceptance Model Predict Actual Use? A Systematic Literature Review", Information and Software Technology, Vol. 52, No. 5, pp. 463-479.

Venkatesh, V. and Davis, F.D. (2000) "A Theoretical Extension of the Technology Acceptance Model: Four Longitudinal Field Studies”, Management Science, Vol. 46, No. 2, pp. 186-204.

Venkatesh, V., Speier, C. and Morris, M.G. (2002) "User Acceptance Enablers in Individual Decision Making about Technology: Toward an Integrated Model", Decision Sciences, Vol. 33, No. 2, pp. 297-316.

Venkatesh, V., Morris, M.G., Davis, G.B. and Davis, F.D. (2003) "User Acceptance of Information Technology: Toward a Unified View. MIS Quarterly, pp. 425-478.

Venkatesh, V., Thong, J.Y. and Xu, X. (2012) "Consumer Acceptance and Use of Information Technology: Extending the Unified Theory of Acceptance and Use of Technology", MIS Quarterly, Vol. 36, No. 1, pp. 157-178.

Xie, K.L., So, K.K.F., \& Wang, W. (2017) "Joint Effects of Management Responses and Online Reviews on Hotel Financial Performance: A Data-Analytics Approach", International Journal of Hospitality Management, Vol. 62, pp. 101-110.

$\mathrm{Wu}, \mathrm{B}$. and Chen, X. (2017) "Continuance Intention to Use MOOCs: Integrating the Technology Acceptance Model (TAM) and Task Technology Fit (TTF) Model", Computers in Human Behavior, Vol. 67, pp. 221-232. 


\section{Appendix A: The discriminant validity index}

\begin{tabular}{|l|l|l|l|c|c|c|c|c|c|c|c|c|}
\hline & Construct & \multicolumn{2}{l|}{ Items } & $\mathbf{1}$ & $\mathbf{2}$ & $\mathbf{3}$ & $\mathbf{4}$ & $\mathbf{5}$ & $\mathbf{7}$ & $\mathbf{8}$ & $\mathbf{9}$ & $\mathbf{1 0}$ \\
\hline 1 & Pace of Technological Innovation & PTI & 6 & $\mathbf{0 . 8 8 9}$ & & & & & & & \\
\hline 2 & Perceived Usefulness & PU & 3 & $0.512^{*}$ & $\mathbf{0 . 9 0 6}$ & & & & & & \\
\hline 3 & Perceived Ease of Use & PEoU & 4 & -0.725 & 0.675 & $\mathbf{0 . 8 6}$ & & & & & \\
\hline 4 & Social Influences & SI & 3 & 0.531 & $0.392^{*}$ & 0.712 & $\mathbf{0 . 8 4 9}$ & & & & \\
\hline 5 & Behavioral Intention & BI & 3 & $0.767^{*}$ & -0.232 & 0.722 & 0.761 & $\mathbf{0 . 9 5 4}$ & & & \\
\hline 6 & Interactive Engagement & IE & 7 & 0.743 & $0.193^{*}$ & 0.723 & -0.743 & $0.634^{* *}$ & $\mathbf{0 . 9 3 8}$ & & \\
\hline 7 & Age & GDR & 1 & 0.021 & -0.032 & -0.011 & $0.017^{*}$ & $0.003^{*}$ & -0.125 & N/A & \\
\hline 8 & Gender & AGE & 1 & 0.111 & -0.015 & -0.011 & -0.003 & $0.002^{* *}$ & 0.005 & $0.012^{*}$ & N/A & \\
\hline 9 & Experience & EXP & 1 & 0.03 & $0.022^{*}$ & -0.017 & $0.011^{* *}$ & 0.021 & 0.104 & $0.101^{*}$ & $0.092^{*}$ & N/A \\
\hline
\end{tabular}

Note:

1) The discriminant validity was assessed by comparing the square root of each AVE in the diagonal with the correlation coefficients (off-diagonal) for each construct in the relevant rows and columns.

2) $* \mathrm{p}<0.05 ; * * \mathrm{p}<0.01 ; * * * \mathrm{p}<0.001$; all other correlations are insignificant. 3. Bold diagonal elements are AVEs and off-diagonal elements are correlations. 
